\title{
Climatic zonation and weathering control on sediment composition (Angola)
}

\author{
Pedro Dinis $^{1 *}$, Eduardo Garzanti $^{2 *}$, Pieter Vermeesch $^{3}$, João Huvi ${ }^{4}$
}

1 MARE-Marine and Environmental Sciences Centre, Departamento de Ciências da Terra, Universidade de Coimbra, 3030- 790 Coimbra, Portugal

${ }^{2}$ Department of Earth and Environmental Sciences, University of Milano-Bicocca, 20126, Milano, Italy

${ }^{3}$ University College London, London, WC1E 6BT, UK

${ }^{4}$ Marine and Environmental Sciences Centre, University Katiavala Bwila, Angola

* Corresponding authors*

\section{ABSTRACT}

Complementary mineralogical and geochemical datasets on fluvial, beach and dune samples collected along the Atlantic margin of subequatorial southwestern Africa are used to investigate the relationships between provenance and climatic controls on sediment composition and to test the reliability of different geochemical and mineralogical weathering proxies as climatic indicators. The studied N/S-trending coastal region is characterized by strong latitudinal and inland climatic gradients, and thus represents an excellent natural laboratory in which to study the effects of climatic-induced weathering on sediment composition. Although the mineralogy and geochemistry of suspended-load muds closely reflects the different weathering intensities over both latitudinal and inland climatic gradients, the composition of mud and sand samples are strongly affected by sediment provenance. Consequently, weathering parameters such as the $\alpha^{\mathrm{Al}} \mathrm{E}$ values (estimating the degree of depletion in element E relative to the UCC standard), display complex patterns of variation especially for sand samples. By assuming a typical order of bulk-sediment mobility Na > $\mathrm{Ca}>\mathrm{Sr}>\mathrm{Mg}>\mathrm{K}>\mathrm{Ba} \approx \mathrm{Rb}$, anomalously high or low $\alpha^{\mathrm{Al}}$ values placing a specific element off the expected mobility order are considered as an indicator of source-rock control on sediment composition. The composition of detritus recycled from Meso-Cenozoic strata reflects the cumulative effect of successive sediment cycles, with recycling processes affecting to a different extent the diverse weathering proxies. In particular, $\alpha^{\mathrm{Al}} \mathrm{Na}$ appears to be more strongly affected by recycling in muds than in sands. Among all mineralogical and chemical parameters, those that correlate best with rainfall in the drainage areas are $\alpha^{\mathrm{Al}} \mathrm{Na}$ for sands, $\alpha^{\mathrm{Al}} \mathrm{Mg}$ for muds and smectite content (only in areas of low rainfall). In the geological and geomorphological setting of SW Africa 
these proxies turn out to be better climate estimators than the classical weathering indices CIA or WIP. This case study reminds us to carefully consider source-rock control and mixing with recycled detritus when drawing inferences on climatic conditions based on weathering indices.

Keywords: Weathering geochemistry; Clay mineralogy; Arid tropical climate; Humid equatorial climate; Angolan passive margin

5

\section{Introduction}

Classically used weathering indices depend strongly on source area geology (e.g., Gaillardet et al., 1999; Borges et al., 2008; Dinis and Oliveira, 2016). So much that in geological active settings they may reflect the lithology of source rocks as much as the geochemical ratios for non-mobile elements usually regarded as provenance indicators (Garzanti and Resentini, 2016). Sorting processes (Garzanti et al., 2010), the presence of non-silicate carbonate (Buggle et al., 2011) and diverse diagenetic transformations (Fedo et al., 1995; Morton and Hallsworth, 2007) pose supplementary difficulties in the interpretation of sediment composition in terms of weathering intensity, to the extent that one may even conclude that the actual weathering stage can only be assessed safely in a regolith sequence from a comparison with the regolith's parent rock.

The Atlantic passive margin of southern Africa, oriented perpendicular to latitude-controlled climatic zonation and stretching from the Tropic of Capricorn to the equatorial zone (Fig. 1), is an exceptionally well suited natural laboratory in which to investigate the influence of climate and chemical weathering on sediment composition using multiple proxies. Sediments generated in this area should reflect not only the latitudinal climatic gradient but also the marked inland climatic gradient between the dry coastal zone and wet hinterland highlands, as well as the physiography of river catchments and depositional areas. The Angolan continental margin shows laterally extensive tectonic units, including Archean to Mesoproterozoic basement rocks ranging in composition from predominantly felsic to subordinately mafic, Neoproterozoic mobile belts with diverse metamorphic grades and Meso-Cenozoic sedimentary successions with local intercalation of basaltic lavas, providing suitable conditions to investigate the effects of parent-rock lithology and recycling on modern sedimentary products.

The present research is focused on geochemical and mineralogical weathering proxies for river sands, river muds and beach and aeolian sands collected in sub-equatorial southwestern Africa across ca. 15 degrees of latitude from Namibia to the Congo. The information on climatic conditions deduced from weathering proxies based on sediment chemical composition and clay 
mineralogy are discussed taking systematically into account the rainfall in the source areas and the different proportions of diverse parent rocks in each drainage basin as quantified accurately with GIS tools. The principal aim of this article is to discuss and outline the potential and limitations of the use of mineralogical and geochemical parameters as climatic proxies in a well suited modern natural laboratory.

\section{Geology and Geomorphology}

\subsection{Geological framework}

Basement rocks of the southwestern Africa continental margin include part of the Congo and Kalahari cratons together with several Neoproterozoic to Cambrian orogenic belts associated with their collision and consequent amalgamation of West Gondwana (Basei et al., 2008; Heilborn et al., 2008; Vaughan and Pankhurst, 2008). The Congo Craton is welded at its southern tip to the Kalahari Craton by the Kaoko Belt, representing the northern coastal branch of the Damara Belt (Fig. 1E). In subequatorial western Africa, the Congo Craton is represented by the Angola Block (de Waele et al., 2008), the core of which mostly consists of felsic Eburnean ( 2 Ga) plutonic and high-grade metamorphic rocks (Carvalho, 1984; Carvalho et al., 2000; Pereira et al., 2011). Close to its northeastern limit, Neoarchean granites, gneisses and migmatites occur together with mafic complexes, being this set of rocks collectively called Liberian-Limpopo massifs (Carvalho, 1984; Carvalho et al., 2000). The widest mafic intrusions are found in the Cunene Intrusive Complex at the southeastern limit of the Angola Block. The Kaoko Belt comprises a high-grade metamorphic basement covered by metasedimentary units and intruded by Pan-African igneous rocks (Miller, 2008). The West Congo Belt comprises even older metasediments, together with both mafic and felsic volcanic and volcano-sedimentary units covered by diverse siliciclastic and carbonate formations constituting the West Congolian Group (Tack et al., 2001). Both Kaoko and West Congo belts display progressively increasing metamorphic grade from only mildly deformed Neoproterozoic foreland units in the east to high grade rocks in the west.

Along the West African margin, the Precambrian to Paleozoic basement is covered by mostly upper Cretaceous to Cenozoic stratigraphic successions deposited during and after the late early Cretaceous opening of the central South Atlantic Ocean (Moulin et al., 2005; Aslanian et al., 2009; Chaboureau et al., 2013). These units accumulated in distinct depocenters (i.e., Congo, Cuanza, Benguela and Namibe basins; Fig. 1E), which recorded the northward progression of rifting and sea-floor spreading (Moulin et al., 2010; Chaboureau et al., 2013). The Atlantic margin to the north of the Walvis Ridge is mainly volcanic-poor (Contrucci et al., 2004) and characterized by thick 
post-break-up evaporite units and major lower Cretaceous to Neogene siliciclastic strata (Séranne and Anka, 2005). Syn-rift late early Cretaceous mafic volcanism in southwest Africa is best represented by the Etendeka lavas (Renne et al., 1996), which are extensive south of the Walvis Ridge but represented locally also at lower latitudes (Marzoli et al., 1999). Mainly Cenozoic fluvial and aeolian sediments are found in the hinterland as part of the Mega-Kalahari sequence (Haddon and McCarthy, 2005).

\subsection{Climatic gradients}

Two major and broadly perpendicular climatic gradients can be recognized in the southeast Atlantic region between $5^{\circ} \mathrm{S}$ and $20^{\circ} \mathrm{S}$. One is latitude-controlled and reflects the transition from hyperarid Namibia to hyperhumid Congo. The other reflects the rapid progressive increase in humidity landward, such that average annual rainfall ranges from $<100 \mathrm{~mm}$ in the coastal fringe to $\sim 1500$ $\mathrm{mm}$ in the sub-equatorial hinterland. The latitudinal gradient is particularly evident in the continental interior, where the isohyets trend approximately E-W (Fig. 1B). Unlike rainfall, average annual temperatures do not vary significantly throughout the territory, spanning from $21-27^{\circ} \mathrm{C}$ in the sub-equatorial region north of $10^{\circ} \mathrm{S}$ to $20-24^{\circ} \mathrm{C}$ at higher latitudes (Diniz, 2006). The only exceptions are the most elevated highlands and the desert coastal zone, where average temperatures may be as low as $15^{\circ} \mathrm{C}$.

The aridity of the southern region results from the influence of quasi-stationary anticyclonic conditions that characterize most austral Africa coupled with the Benguela upwelling system, which is responsible for low sea-surface temperatures and low-humidity southerly winds (Lancaster, 2002). Equatorial and sub-equatorial areas are under the influence of the Walker upward air circulation (Hastenrath, 2012) and the warm Angola Current, which is considered the eastern section of the Guinea (or Angola) gyre (Gordon and Bosley, 1991; Wacongne and Piton, 1992). The Benguela Current flows northward from off the Cape of Good Hope along the east Atlantic edge equatorward as far as $\sim 20^{\circ} \mathrm{S}$, where it starts to converge with the warm southward-flowing Angola Current forming the Angola-Benguela Front (Meeuwis and Lutjeharms, 1990; Shannon and Nelson, 1996; Kostianoy and Lutjeharms, 1999).

In accordance to this atmospheric and oceanic circulation pattern, aridity becomes less severe north of the Angola-Benguela Front. Climate thus shifts from hot desert in coastal Namibia and southern Angola, to hot semi-arid in the coastal Benguela region, and finally to tropical savanna towards the border with the Democratic Republic of Congo. Inland, climate becomes humid subtropical or temperate-highland tropical with dry winters at higher elevation (Peel et al., 2007). Responding to 
seasonal changes in radiation and atmospheric and oceanic circulation patterns, regional climate is characterized by alternating wet and dry seasons varying with latitude and distance from the coastline. The rainy season tends to coincide with the period of highest mean temperatures and, depending on the region, starts between September and November and lasts from 4 to 8 months until March to May, being longer inland, in particular at lower latitudes (Diniz, 2006). The months of higher rainfall are usually January and February, or March in the lower latitude coastal areas. Along the extremely arid southern coastal fringe, rainfall is so rare that no wet season really exists.

\section{Methods}

To investigate the effects of chemical weathering on sediment composition, in June 2015 we sampled, along the banks or on the dry bed of all major rivers in Angola, 23 freshly deposited muds considered as proxy for suspended load, and 24 sands considered as proxy for bedload. We also collected 38 beach sands and 2 Moçâmedes dune sands. Together with additional 19 river sands, 15 beach sands and 5 Moçâmedes dune sands, some presented in previous works (Garzanti et al., 2014a, 2014b) , our set of 137 sediment samples covers the entire subequatorial Atlantic margin of Southern Africa (Fig. 1D). Detailed information on sampling sites is provided in Appendix Table A1.

\subsection{Clay minerals}

For 22 mud samples, the mineralogy of the $<2 \mathrm{~mm}$ fraction separated by centrifuging was determined by X-ray powder-diffraction (XRD) on oriented mounts, using a Philips ${ }^{\circledR}$ PW 3710 equipment with $\mathrm{CuK} \alpha$ radiation. Mineral proportions were evaluated semi-quantitatively using diagnostic XRD peak areas (Moore and Reynolds, 1997; Kahle et al., 2002), weighted by empirical factors (Schultz, 1964). The complete dataset is provided in Appendix Table A3.

\subsection{Geochemistry}

Split aliquots obtained by wet sieving of the $<32 \mu \mathrm{m}$ fraction for 17 mud samples and of the 63-2000 $\mu \mathrm{m}$ fraction for 41 river, beach and aeolian-dune sand samples were analysed at ACME Laboratories (Vancouver). Major oxides and some minor elements were determined by ICP-AES and trace elements by ICP-MS, following a lithium metaborate/tetraborate fusion and nitric acid digestion. For further information on adopted procedures, geostandards used and precision see http://acmelab.com (group 4A-4B and code LF202). 
150 To estimate weathering we used several chemical indices, including the CIA (Chemical Index of 151 Alteration of Nesbitt and Young, 1982), CIX (Chemical Index of Alteration that does not consider $152 \mathrm{CaO}$; Garzanti et al., 2014a) and the WIP (Weathering Index of Parker, 1970), calculated using 153 molecular proportions of mobile alkali and alkaline earth metals corrected for $\mathrm{Ca}$ in apatite. No correction for $\mathrm{Ca}$ in carbonates was applied because carbonate grains are present only very locally and in minor amounts in Angolan sediments. Weathering intensities can also be calculated for each element mobilized during incongruent weathering of silicates by comparing its concentration to that of a non-mobile element in our samples and in the Upper Continental Crust standard (UCC; Rudnick and Gao, 2003; $\mathrm{Hu}$ and Gao 2008). The ratio of a single mobile element ( $\mathrm{Mg}, \mathrm{Ca}, \mathrm{Na}, \mathrm{Sr}, \mathrm{K}, \mathrm{Ba})$ to a non-mobile element with similar magmatic compatibility ( $\mathrm{Al}, \mathrm{Ti}, \mathrm{Sm}, \mathrm{Nd}$, Th), called $\alpha$ value, was proposed originally by Gaillardet et al. (1999) to minimize uncertainties related to the assumed composition of crustal source rocks and to the effect of quartz dilution and thus partly also of grain size and recycling. The non-mobile elements $\mathrm{Th}, \mathrm{Nd}, \mathrm{Sm}$, and $\mathrm{Ti}$, however, are preferentially hosted in dense and ultradense minerals (e.g., monazite, allanite, titanite, ilmenite, rutile) that can be strongly concentrated by hydrodynamic processes. Consequently, $\alpha$ values are prone to yield very misleading results for samples strongly enriched in heavy minerals by hydraulic processes (Garzanti et al., 2009). Hydraulic-sorting bias can be reduced effectively by referring to a common non-mobile element such as $\mathrm{Al}$, which is not hosted mainly in ultradense minerals. The $\alpha^{\mathrm{Al}}$ values for any element $\mathrm{E}$, defined as $\alpha_{\mathrm{E}}^{\mathrm{Al}}=\mathrm{Al} / \mathrm{E}_{\text {sample }} / \mathrm{Al} / \mathrm{E}_{\mathrm{UCC}}$, proved to be much more consistent and reliable indicators of weathering (Garzanti et al., 2013a,b), and are thus recommended in any weathering studyFormulas for calculating weathering indices are given in Table 1. The complete geochemical dataset is provided in Appendix Table A2.

\section{Results}

\subsection{Clay Mineralogy}

Clay-mineral assemblages in river muds from SW Africa contain variable proportions of kaolinite, which is usually the most common mineral, expansive clays (mainly smectite) and mica-illite (Fig. 2). Rivers of southernmost Angola (Curoca and Bero, $15-16^{\circ} \mathrm{S}$ ) carry subequal amounts of kaolinite and expansive clays, with minor mica-illite. Kaolinite becomes prevalent northwards, where expansive clays tend to decrease. Mica-illite is particularly abundant in muds collected between $14^{\circ} \mathrm{S}$ and $12.3^{\circ} \mathrm{S}$. River muds sampled between $13^{\circ} \mathrm{S}$ and $10.5^{\circ} \mathrm{S}$ yield major amounts of kaolinite, subordinate mica-illite and no or limited amounts of expansive clays. Expansive clays become common again in muds collected between $10^{\circ} \mathrm{S}$ and $8.6^{\circ} \mathrm{S}$. Finally, kaolinite dominates over mica- 
illite with minor or absent expansive clays in river muds of northern Angola (Dande to Congo) sampled north of $8.6^{\circ} \mathrm{S}$.

\subsection{Geochemistry of river muds}

When compared to the UCC, river muds tend to be depleted in most alkali and alkaline-earth metals, and most strongly in $\mathrm{Na}$ (Fig. 3). Southern latitude samples (> 15ㅇ) are more depleted in $\mathrm{Na}$ in the hinterland than in coastal settings. Mid-latitude muds $\left(10-15^{\circ} \mathrm{S}\right)$ usually show lower $\mathrm{Na}$ depletion than the remaining samples. The other elements may show moderate enrichment or depletion relative to the UCC. Enrichment in rare earth and high field strength elements is marked in samples collected at intermediate latitudes but not in those collected at higher latitude ( $\left.>15^{\circ} \mathrm{S}\right)$, which may even be depleted regardless to distance from the Atlantic coast. Non-mobile elements tend to be enriched more than mobile elements.

\subsection{Geochemistry of river, beach and aeolian sands}

Relative to the UCC standard, river sands are enriched in $\mathrm{SiO}_{2}$ and generally depleted in other oxides (Fig. 3). Depletion is particularly marked for $\mathrm{MgO}, \mathrm{CaO}$ and $\mathrm{Na}_{2} \mathrm{O}$, and tends to be higher at lower latitudes $\left(<10^{\circ} \mathrm{S}\right)$. River sands at higher latitudes may be moderately enriched in $\mathrm{K}_{2} \mathrm{O}$ and $\mathrm{TiO}_{2}$. $\mathrm{Ba}, \mathrm{Zr}$, Hf and $\mathrm{Cr}$ may be also enriched locally relative to the UCC standard, whereas Rb, Sr, $\mathrm{Eu}, \mathrm{U}, \mathrm{Nb}, \mathrm{Ta}, \mathrm{Co}, \mathrm{Ni}$ and $\mathrm{Ga}$ are generally notably depleted. River sands from low (< $\left.10^{\circ} \mathrm{S}\right)$, intermediate $\left(10-15^{\circ} \mathrm{S}\right)$ and high latitudes $\left(>15^{\circ} \mathrm{S}\right)$ do not show major differences in the concentration of trace elements.

Beach deposits from low latitudes $\left(<10^{\circ} \mathrm{S}\right)$ are generally strongly to moderately depleted in $\mathrm{Al}_{2} \mathrm{O}_{3}$, $\mathrm{Fe}_{2} \mathrm{O}_{3}, \mathrm{TiO}_{2}$ and $\mathrm{MnO}$, whereas those from higher latitudes display lower levels of depletion or show moderate enrichment in these oxides. Non-mobile elements (e.g., heavy REE, Sc, Y, Zr, and $\mathrm{Cr}$ ) tend to show lower levels of depletion or moderate enrichment relative to the UCC, and their concentrations tend to be higher at lower latitudes.

\section{Weathering control on sediment composition}

\subsection{Chemical evidence of weathering}

The mobility of alkali and alkaline-earth metals, classically used to evaluate the intensity of chemical weathering in source areas, is negligible in sediments of coastal Namibia (Garzanti et al., 2014a) and very low even in river sands of southern and central Angola, where the CIA is $52 \pm 3$ and most $\alpha^{\mathrm{Al}}$ values are close to 1 . In contrast, notable element mobility is indicated in sands of northern 
216 Angola (Mebridege, Luculu and Congo Rivers draining the M'banza Congo province), where the 217 CIA increases to $72 \pm 12, \alpha^{\mathrm{Al}} \mathrm{Na}$ to $5 \pm 4$ and other $\alpha^{\mathrm{Al}}$ values are 2-3. Okavango, Cuando and Zambezi 218 sands generated in southeastern Angola yield comparable values of CIA $(74 \pm 5)$ and $\alpha^{\mathrm{Al}} \mathrm{Na}(4 \pm 1)$, 219 and the other $\alpha^{\mathrm{Al}}$ values are $\leq 3$ (Garzanti et al., 2014a). Geochemical information provided in 220 Dupré et al. (1996) allowed us to calculate CIA values of $64 \pm 10$ and $\alpha^{\mathrm{Al}} \mathrm{Na}$ of $8 \pm 7$ for bedload 221 sands carried by the Congo River draining the wet equatorial region. North of the Congo River, 222 close to the Equator, the CIA reaches $87 \pm 7$ and $\alpha^{\mathrm{Al}} \mathrm{Na} 8 \pm 6$ in river sands; other $\alpha^{\mathrm{Al}}$ values are still $223 \sim 2$.

224 Virtually negligible depletion in alkali and alkaline-earth elements was also found for river muds of 225 Namibia, where the CIA is $52 \pm 6$ and $\alpha^{\mathrm{Al}}$ values are close to $\sim 1$ (Garzanti et al., 2014a). Instead, 226 significant element mobility is indicated in muds carried by northern Angolan rivers draining into 227 the Atlantic Ocean (CIA is $85 \pm 4 ; \alpha^{\mathrm{Al}} \mathrm{Na}$ is 12.6-37.1). Similar values were obtained for Okavango, 228 Cuando and Zambezi muds (CIA is $81 \pm 2 ; \alpha^{\mathrm{Al}} \mathrm{Na}$ is $19.5 \pm 0.3$ ) generated in southeastern Angola 229 (Garzanti et al., 2014a). The classic grain-size control on composition (e.g., von Eynatten et al., $2302012,2016)$ is clearly displayed by the consistently greater degree of element mobility shown by 231 river muds relative to river sands at any latitude.

232 In summary, chemical data on river sediments document notably increasing weathering effects at 233 lower latitudes (Fig. 3). Additionally, stronger weathering characterize sediments carried by major 234 rivers draining vast areas of the wet hinterland contrasting with sediments generated in larger 235 proportions closer to the coastal zone. Beach and dune samples also reflect the effects of latitudinal and inland gradients (Fig. 3).

\subsection{Clay-mineral evidence of weathering}

239 The behaviour of chemical indices of weathering is paralleled by trends of variation in clay-mineral assemblages (Fig. 2). Kaolinite is more abundant in lower latitude river sediments, reflecting more advanced weathering intensity in the subequatorial belt. Apart from the influence of source area geology, which is discussed below, the increasing abundance of expansive clays south of the 243 Catumbela mouth $\left(13.5^{\circ} \mathrm{S}\right)$ reflects a notable decrease in weathering intensity. Illite formed during early stages of feldspar weathering tends to have $\mathrm{Al}$ in the octahedral positions, which is frequently identified in XRD analyses by a relatively high ratio between the intensities of $5 \dot{A}$ and $10 \dot{A}$ reflections (I5/I10; Esquevin, 1969), as found in river muds collected at both northern $\left(<10^{\circ} \mathrm{S}\right)$ and

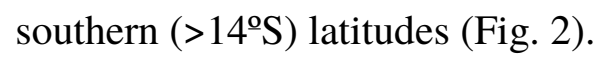




\subsection{Comparison of multiple datasets}

250 The part of the dataset that we used for statistical analysis comprises over 2,500 numerical values 251 spanning 74 samples and two sediment types (sand and mud), characterized by 36 different 252 compositional parameters including 9 major elements, 24 trace elements, and 3 clay minerals. Our 253 aim is to use these data (1) to quantify the compositional similarities and differences between the 254 samples and assess whether there is a geographic or climatic control on the sand and mud 255 composition; (2) to compare the composition of sand and mud samples. These two aims are 256 achieved by two statistical techniques: principal component analysis and 3-way multidimensional 257 scaling.

\subsubsection{Principal Component Analysis (PCA)}

260

Figure 4 shows the results of a PCA of all the sand samples in the Angolan database, including 20 river samples and 29 beach and dune samples. The river samples are further divided into a northern (blue), central (green) and southern (red) group, whereas the beach and dune samples are shown in grey. These 49 samples were compared using 26 compositional parameters: $\mathrm{Si}, \mathrm{Al}, \mathrm{Fe}, \mathrm{Mg}, \mathrm{Ca}, \mathrm{Na}$, K, Ti, P, Rb, Sr, Ba, Y, La, Ce, Pr, Nd, Sm, Eu, Gd, Tb, Dy, Ho, Er, Tm, Yb, Lu, Th, U, Zr, Hf, Nb and Ga. Major element concentrations were converted from weight percentages of oxides to ppm units of the elemental form. The resulting values were subjected to a centred log-ratio transformation in order to free the compositional data from the unit sum constraint (Aitchison, 1986).

The results show a geographical dependence of the sand compositions, with the northern and southernmost river samples being separated into two distinctive compositional groups. It is important to note that the northern samples also plot close to the beach samples of similar latitude, indicating that those beach sands are locally derived. This local provenance contrasts starkly with the southern beach and dune samples, which bear little or no compositional resemblance to the southern rivers. The vector loadings of the first principal component are dominated by incompatible elements such as $\mathrm{K}$ and $\mathrm{Rb}$, whereas the second principal component attaches stronger weight to compatible elements such as $\mathrm{Mg}$ and $\mathrm{Ca}$.

Because PCA requires that the number of input variables does not exceed the number of samples it was necessary to select a subset of the 26 elements for further analysis. We chose those elements exhibiting a large spread (high coefficient of variation) but no strong correlation with other. Based 
on these criteria, the following variables were selected: $\mathrm{Si}, \mathrm{Al}, \mathrm{Fe}, \mathrm{Ca}, \mathrm{Na}, \mathrm{K}, \mathrm{Ti}, \mathrm{P}, \mathrm{Rb}, \mathrm{La}, \mathrm{Ce}, \mathrm{Eu}$, $\mathrm{Th}, \mathrm{U}, \mathrm{Zr}$ and $\mathrm{Nb}$. The PCA map of the mud samples shows an even clearer latitudinal dependence of the chemical compositions than the sand (Fig. 4). The vector loadings of the principal components are dominated by $\mathrm{Si}, \mathrm{Al}, \mathrm{Zr}, \mathrm{Fe}$ and $\mathrm{Na}$, elements that are either enriched or depleted during chemical weathering. This naturally leads to the interpretation that the latitudinal dependence of the mud compositions is due to the differential weathering intensities over the strong climatological gradient (Fig. 1B), although a second order lithological effect cannot be ruled out either.

\subsubsection{3-way multidimensional scaling (MDS) analysis of the river samples}

It would be useful to combine and compare the two sample sets to find structure in three 'levels' worth of information, comparing multiple samples (1st level) using their composition (2nd level) in multiple sediment types (3rd level). '3-way multidimensional scaling' is designed to deal precisely with this class of problem (Vermeesch and Garzanti, 2015). First, we construct a 3-dimensional data structure populated by the log-ratio distances between the 17 sampling sites that provided 5 different proxies: the major (1st proxy) and trace (2nd proxy) element compositions of the sand fraction, the major (3rd proxy) and trace (4th proxy) element compositions of the mud fraction, and the clay mineralogy (5th proxy). The resulting 5x17x17 tensor is then fed into a 3-way MDS algorithm, which returns two pieces of graphical information (Fig. 5). The first piece is the 'group configuration'. This is a map in which similar samples plot close together and dissimilar samples plot far apart. The second piece of graphical output produced by 3-way MDS does not show the samples but the proxies. This scatter plot shows the 'weights' attached by each of these proxies to the horizontal and vertical dimension of the group configuration.

For the Angolan dataset, the sand compositions attach a heavy weight (1.2) to the horizontal dimension and a lighter weight (0.8) to the vertical dimension. In contrast with the sand, the clay composition attaches more weight to the vertical dimension (1.6) than the horizontal dimension (0.4). The source weights attached to the mud compositions lie in between those of the sand and clay. This indicates that the mud composition is governed by both weathering intensity and lithology, with an emphasis on the former. In summary, the 3-way MDS configuration reveals a strong latitudinal dependence of sediment composition due to a combination of weathering and lithology.

\section{The influence of source-rock lithology}


313 Values of $\alpha^{\mathrm{Al}} \mathrm{Mg}$ notably higher than $\alpha^{\mathrm{Al}} \mathrm{Na}, \alpha^{\mathrm{Al}} \mathrm{Sr}$ and $\alpha^{\mathrm{Al}} \mathrm{Ca}$ for river sands collected between $15^{\circ} \mathrm{S}$ 314 and $10^{\circ} \mathrm{S}$, and the opposite behavior of $\alpha^{\mathrm{Al}} \mathrm{K}$ (Fig. 3), along with $\alpha^{\mathrm{Al}} \mathrm{Ba}$ and $\alpha^{\mathrm{Al}} \mathrm{Rb}$, clearly indicate 315 that sediment composition is largely determined by the lithology of source rocks. Rivers flowing in 316 this latitudinal sector, contrary to regions in the north and south, drain mainly felsic igneous rocks 317 and associated metamorphic units, explaining the scarcity of $\mathrm{Mg}$ in their sands. Instead, mafic rocks 318 are widely exposed in the catchment of southern Angola rivers, namely the Cunene Intrusive 319 Complex (occupying 4.4\%, $15.8 \%$ and $12.8 \%$ of the drainage areas of Cunene, Curoca and 320 Giraul, respectively), and are also common in the Limpopo-Liberian at the northern edge of the 321 Angola Block (Carvalho, 1984; Carvalho et al., 2000), being potential sources of material for part 322 of the studied sediments.

323 River sands between the Catumbela and Cuanza courses, yield higher $\alpha^{\mathrm{Al}} \mathrm{Mg}$ and $\alpha^{\mathrm{Al}} \mathrm{Ca}$ values when 324 sourced almost exclusively by Precambrian felsic units (Balombo and Keve rivers), and lower values where significant proportions of the drainage areas extend through the Cuanza and Benguela sedimentary basins (Longa and Quicombo rivers), thus suggesting the presence of common $\mathrm{Mg}$ and $\mathrm{Ca}$ sources in the coastal region. Voluminous mafic units are found in the Cuanza Volcanic Seamount (Marzoli et al., 1999), which intercepts the continent some $100 \mathrm{~km}$ to the north of the Catumbela River outlet, and in smaller scattered outcrops farther to the north (Carvalho, 1980; Araújo and Perevalov, 1998). The incorporation of sediment sourced from these rocks and carbonate units exposed in sub-equatorial regions with higher rainfall contributes to explain occasional decreases in $\alpha^{\mathrm{Al}} \mathrm{Mg}$ and $\alpha^{\mathrm{Al}} \mathrm{Ca}$ (Fig. 3). In fact, sediments collected in rivers that drain wider areas of the Meso-Cenozoic basins tend to yield lower $\alpha^{\mathrm{Al}} \mathrm{Mg}$ and $\alpha^{\mathrm{Al}} \mathrm{Ca}$ values, and this relation is particularly clear at higher latitudes where weathering is less intense and sediment composition affected more by source rock lithology (Fig. 6).

336 Clay mineral assemblages also reflect in part the lithology of source rocks. Smectite formation close 337 to the coast was favored by the presence of basalts. Expansive clays were in fact generated by soil338 forming processes in floodplain deposits of the coastal Benguela region (Dinis et al., 2016) and smectite formation in Meso-Cenozoic basins is also reflected in the greater abundance of expansive clays in rivers draining wider areas within these sedimentary basins (Fig. 6). Mica-illite tends to be more abundant between $12^{\circ}$ and $14^{\circ} \mathrm{S}$, where the I5/I10 ratio is lower, indicating more $\mathrm{Fe}-\mathrm{Mg}$ and less $\mathrm{Al}$ in the octahedral position (Esquevin, 1969). Illite with low I5/I10 is also observed in the 343 South Atlantic Ocean, where it is ascribed to the disintegration of biotite (Petschick et al., 1996). Its presence in West Angola sediments thus points to provenance from the biotite-rich granitoids and metamorphic rocks well represented south of the Cuanza course (Carvalho, 1980, 1984; Araújo and Perevalov, 1998; Carvalho et al., 2000; Pereira et al., 2011). 


\section{Recycling effect on weathering proxies}

349 The weathering indices characterizing a sedimentary unit may not refer to the last depositional cycle 350 only, but they may be inherited through reworking of older sedimentary units. Sediments generated in large catchments generally include grains that passed through several exogenous cycles and their composition thus reflects such cumulative effect (Gaillardet et al., 1999). This is the case of the Congo the Cuanza and the Cunene rivers that drain the sedimentary units of the hinterland. Because of the strong northward longshore sediment transport, the same holds true for littoral dune and beach sands fed by these rivers. The incorporation of recycled grains and consequent effect on sand composition is particularly extensive for southern coastal deposits of the Moçamedes desert that include major amounts of sand supplied by the Orange River (Garzanti et al., 2014c, 2017).

358

Recycling effects can be assessed by comparing chemical indices that are strongly controlled by quartz dilution, such as the WIP, versus the CIA or CIX, which are not affected (Garzanti et al., 2013a). To avoid local anomalies caused potentially by the occurrence of carbonate grains, the CIX rather than the CIA will be used for this purpose (Fig. 7). Beach samples from different regions largely overlap in the CIX vs. WIP diagram. Varying proportions of recycled quartz is reflected by the higher scatter of WIP values in mid latitudes, with higher values (i.e. minor recycling) where Precambrian basement outcrops reach close to the coast. River sands of the upper Cunene as far downstream as Ruacana, and of the Cuanza and Bengo rivers also yield low WIP values, reflecting significant quartz dilution and sediment reworkingThe composition of river muds is less affected by quartz dilution, being plotted along a line parallel to UCC weathering trend.

$\mathrm{Th} / \mathrm{Sc}$ vs. $\mathrm{Zr} / \mathrm{Sc}$ plots classically used to infer the nature of source rocks and recycling control on sediment composition (McLennan et al., 1993), with a third dimension added to represent geochemical weathering proxies (bubble size), provide further clues on the effect of sediment reworking on elements concentrations (Fig.8). River sands with a larger recycled component (i.e., spreading towards higher $\mathrm{Th} / \mathrm{Sc}$ values) tend to show lower $\alpha^{\mathrm{Al}} \mathrm{Mg}$ and $\alpha^{\mathrm{Al}} \mathrm{Ca}$, confirming a sediment contribution from the Cretaceous volcanic rocks of the Atlantic margin (Fig. 6), and higher CIX. The effects of reworking for mud samples are revealed by an increase in $\alpha^{\mathrm{Al}} \mathrm{Na}$. Lower $\mathrm{Na}$ depletion is in fact observed in muds from mid-latitude rivers (10-15º ; Figs 4) draining almost exclusively basement rocks of the Angola Block.

Because of the cumulative effect of successive sediment cycles, reworked sediments tend to yield compositional features indicative of stronger weathering intensity than first cycle deposits. Recycling affects differently different weathering proxies, and the same parameter may be 
380 influenced to a different extent in sand and mud samples. The incorporation of sediments reworked 381 from the Atlantic margin, in particular at higher latitude regions of lower humidity, has opposite 382 effects on weathering proxies (e.g., increase in CIX and $\alpha^{\mathrm{Al}} \mathrm{Na}$, but decrease in kaolinite/smectite 383 ratio, $\alpha^{\mathrm{Al}} \mathrm{Mg}$ and $\left.\alpha^{\mathrm{Al}} \mathrm{Ca}\right)$.

\section{What weathering indices tell us about climate?}

Weathering indices in both river sands and muds carried to the western coast of southern Africa document that the mobility of chemical elements is markedly influenced by the strong latitudecontrolled climatic gradient, from hyperarid conditions in Namibia to hyperhumid conditions in Congo. This gradient is coupled with the E-W trend of increasing aridity from the wet mountainous hinterland to the coast (Fig. 1C). However, the relationship between weathering proxies and climate is not necessarily simple and straightforward. The climate data from Hijmans et al. (2005) were used here to compute rainfall in each river catchments and test the applicability of several geochemical and mineralogical weathering parameters as climate proxies (Fig. 9).

The rather poor correlation between mean annual rainfall and weathering proxies shows that most parameters do not reflect faithfully local climatic conditions. Largely because of recycling effects and inheritance from past geological histories, the CIA, CIX and WIP indices in both river muds and sands are only partially useful to infer rainfall in the catchment area. Best correlated with rainfall are the $\alpha^{\mathrm{Al}} \mathrm{Mg}$ values in river muds. The $\mathrm{Mg}$ content in mafic-derived sediments is usually substantially higher than in felsic-derived sediments, but the divergence between these sediments tends to be attenuated in finer grain-sizes (von Eynatten et al., 2012, 2016), justifying the correlation with rainfall. However, as the $\alpha^{\mathrm{Al}} \mathrm{Mg}$ in muds is still influenced by parent-rock composition (Fig.8), the high values in Keve and Balombo muds, which would overestimate rainfall in the catchment area, reflects the abundance of felsic igneous rocks of the Angola Block and lack of Meso-Cenozoic basins in the catchment. Poorer positive correlations with rainfall are observed for $\alpha^{\mathrm{Al}} \mathrm{Ca}$ in muds and for $\alpha^{\mathrm{Al}} \mathrm{Na}$ and $\alpha^{\mathrm{Al}} \mathrm{Sr}$ in sands. The correlations become slightly better if we exclude the samples collected in small rivers with lowest rainfall, where leaching of even the most mobile elements is limited. The absence of correlation of $\alpha^{\mathrm{Al}} \mathrm{Na}$ for mud sediments with rainfall may be attributed to recycling effects, as $\mathrm{Na}$ content is most strongly influenced by its cumulative depletion during successive sedimentary cycles (Fig.8).

Regarding clay-mineral assemblages, the amounts of expansive clays correlates negatively with rainfall, although the correlation is limited by the frequency of samples without these minerals (Fig.9). The relation is clearer for river sediments in arid regions at higher latitudes. Somewhat 
poorer correlations with rainfall are obtained for kaolinite abundance and expansive clays/kaolinite ratio. Kaolinite formation is conditioned also by relief, being promoted in flat areas where weathering can evolve for long periods of time, and in sediments of southern Africa kaolinite may be inherited from old weathering profiles (Garzanti et al., 2014a), limiting the use of parameters that consider kaolinite content as climate proxies. The strong dependence of mica-illite proportions on source-rock lithology explains the lack of correlation with rainfall.

The same patterns of correlations determined for coastal Angola may not be observed in other geological and/or geomorphological settings. In fact, the abundance of expansive clays and $\alpha^{\mathrm{Al}} \mathrm{Mg}$ in muds only work as reasonable climatic proxies because in the Angolan coastal region dry climatic conditions concur with the presence of basaltic rocks. Weathering proxies can be influenced by numerous environmental factors not considered in full in the present study, including relief, water table, vegetation, soil types and diverse biological effects. Regardless of rainfall, it is expected that weathering progresses rapidly in the flat areas of the hinterland when the water table is close to the surface. On the other hand, expansive clays, typical of tropical vertisols regardless of the nature of parent rocks, can extend over humid equatorial regions wherever leaching is hampered by low topography and poor drainage conditions, and may form in swampy floodplains where climate is somewhat dryer. Finally, sediment may be sourced from distant regions, thus providing information contrasting with local climate.

\section{Conclusions}

River, beach and dune samples from the Atlantic margin of subequatorial southwestern Africa display different degrees of chemical weathering, reflecting both latitudinal and inland climatic gradients. Moreover, sediment composition is markedly affected by the lithology of parent rocks and by local mixing with recycled detritus, so that different weathering indices (e.g., CIA, CIX, WIP and $\alpha^{\mathrm{Al}} \mathrm{E}$ values) do not invariably behave in accord. Extreme values of weathering indices characterize sediments carried by equatorial rivers in northernmost Angola and the Congo, whereas minimum values characterize sediments collected at higher latitudes in southern Angola and Namibia, in particular when generated in small catchments. The latitudinal weathering trend is clearer for river muds, because river sands are more markedly influenced by source-rock lithology. Kaolinite is largely derived from the wet Angola hinterland, whereas expansive clays are mainly sourced in dryer areas along the coast.

Extracting climatic information from the different weathering indices is not straightforward. Estimators of the degree of depletion of some mobile elements (e.g., $\alpha^{\mathrm{Al}} \mathrm{Na}$ for sand and $\alpha^{\mathrm{Al}} \mathrm{Mg}$ for 
mud) and clay mineral assemblages provide more consistent clues than conventional indices such as the CIA and the WIP, but all of these proxies are affected by provenance and recycling as well. Provenance control is easily identified by the comparison between mineralogical and geochemical data, or among the apparent degree of depletion in different mobile elements. Assuming a typical order of bulk-sediment mobility $\mathrm{Na}>\mathrm{Ca}>\mathrm{Sr}>\mathrm{Mg}>\mathrm{K}>\mathrm{Ba} \approx \mathrm{Rb}$, anomalously high or low $\alpha^{\mathrm{Al}}$ values placing a specific element off the expected mobility order and contrasting behavior in $\alpha^{\mathrm{Al}}$ values point to dominantly felsic or mafic lithologies in the source areas. Isolating the effect of the last depositional cycle in recycled sediments is more complex. Recycling has locally a marked effect on weathering parameters, and may affect differently the same parameter in sand and mud samples. The Angolan case highlights the multiple control of latitudinal climatic zonation, longitudinal rainfall gradient and parent-rock lithology, which in a modern setting can be successfully detangled by the careful inspection of integrated mineralogical and geochemical datasets.

\section{ACKNOWLEDGMENTS}

Field work would not be possible without the logistic support of University of Katiavala Bwila, Instituto Superior Politécnico da Tundavala and the personal actions of Manuel Bandeira, Silvano Levy, Margarida Ventura and Carlos Ribeiro, that we warmly acknowledge. The authors are also grateful to Afonso Sampaio, Armanda Trindade and Edson Baptista, that provided samples for this research. Marta Padoan, Alberto Resentini, Sergio Andó and Giovanni Vezzoli carried out many heavy-mineral and petrographic analyses. Careful constructive reviews by two anonymous reviewers were greatly appreciated.

\section{SUPPLEMENTARY MATERIAL}

Supplementary material associated with this article can be found in the online version, at http://dx.doi. . This includes information on sampling sites (Table A1) and the geochemical (Table A2) and clay-mineral (Table A3) datasets. 


\section{REFERENCES}

Aitchison, J., 1986. The statistical analysis of compositional data. London, Chapman \& Hall.

Araújo, A.G. Perevalov, O.V., 1998. Carta de recursos minerais de Angola/Mineral resources map of Angola. Ministério de Geologia e Minas, Instituto Geológico de Angola.

Aslanian, D., Moulin, M., Olivet, J. L., Unternehr, P., Matias, L., Bache, F., Rabineau, M., Nouzé, H., Klingelheofer, F., Contrucci, I., Labails, C., 2009. Brazilian and African passive margins of the Central Segment of the South Atlantic Ocean: Kinematic constraints. Tectonophysics, 468, 98-112.

Basei, M.A.S., Frimmel, H.E., Nutman, A.P., Preciozzi, F., 2008. West Gondwana amalgamation based on detrital zircon ages from Neoproterozoic Ribeira and Dom Feliciano belts of South America and comparison with coeval sequences from SW Africa. Geological Society, London, Special Publications,294, 239-256.

Borges, J.B., Huh, Y., Moon, S., Noh, H., 2008. Provenance and weathering control on river bed sediments of the eastern Tibetan Plateau and the Russian Far East. Chemical Geology, 254, 5272.

Buggle, B., Glaser, B., Hambach, U., Gerasimenko, N., Markovic, S., 2011. An evaluation of geochemical weathering indices in loess-paleosol studies. Quaternary International 240, 12-21.

Carvalho, H., 1980. Geologia de Angola, escala 1:1.000.000, folha 3. Laboratório Nacional de Investigação Cientifica e Tropical.

Carvalho, H., Tassinari, C., Alves, P.H., Guimarães, F., Simões, M.C., 2000. Geochronological review of the Precambrian in western Angola: links with Brazil. Journal of African Earth Sciences, 31, 383-402.

Carvalho, H., 1984. Estratigrafia do Precâmbrico de Angola. Garcia Orta, 7, 1-66.

Chaboureau, A.-C., Guillocheau, F., Robin, C., Rohais, S., Moulin, M., Aslanian, D., 2013. Paleogeographic evolution of the central segment of the South Atlantic during Early Cretaceous times: Paleotopographic and geodynamic implications. Tectonophysics, 604, 191-223.

Contrucci, I,. Matias, L,. Moulin, M., Géli, L., Klingelhofer, F., Nouzé, H., Aslanian, D., Olivet, J.L., Réhault, J.P., Sibuet, J.C., 2004. Deep structure of the West African continental margin (Congo, Zaïre, Angola), between $5^{\circ} \mathrm{S}$ and $8^{\circ} \mathrm{S}$, from reflection/refraction seismics and gravity data. Geophys. J. Int., 158, 529-553.

De Waele, B., Johnson, S. P., Pisarevsky, S. A., 2008. Palaeoproterozoic to Neoproterozoic growth and evolution of the eastern Congo Craton: its role in the Rodinia puzzle. Precambrian Research, $160,127-141$.

Dinis, P.A., Oliveira, A., 2016. Provenance of Pliocene clay deposits from the Iberian Atlantic Margin and compositional changes during recycling.Sedimentary Geology, 336, 171-182.

Dinis, P., Huvi, J., Cascalho, J., Garzanti, E., Vermeesch, P., Callapez, P., 2016. Sand-spits systems from Benguela region (SW Angola). An analysis of sediment sources and dispersal from textural and compositional data. Journal of African Earth Sciences, 117, 171-182.

Diniz, A.C., 2006. Características Mesológicas de Angola. IPAD, Lisboa. 
Dupré, B., Gaillardet, J., Rousseau, D., Allègre, C.J., 1996. Major and trace elements of river-borne material: the Congo Basin. Geochimica et Cosmochimica Acta, 60, 1301-1321.

Esquevin, J., 1969. Influence de la composition cimique des illites sur le cristallinité. Bull. Centre Rech. Pau. S.N.P.A., 3, 147-154.

Ernst, R.E., Pereira, E., Hamilton, M.A., Pisarevsky, S.A., Rodriques, J., Tassinari, C.C., Teixeira, W, Van-Dunem, V., 2013. Mesoproterozoic intraplate magmatic 'barcode'record of the Angola portion of the Congo Craton: Newly dated magmatic events at 1505 and $1110 \mathrm{Ma}$ and implications for Nuna (Columbia) supercontinent reconstructions. Precambrian Research, 230, 103-118.

Fedo, C.M., Nesbitt, H.W., Young, G.M., 1995. Unraveling the effects of potassium metasomatism in sedimentary rocks and paleosols, with implications for paleoweathering conditions and provenance. Geology, 23, 921-924.

Gaillardet, J., Dupré, B., Allègre, C.J., 1999. Geochemistry of large river suspended sediments: silicate weathering or recycling tracer? Geochimica et Cosmochimica Acta, 63, 4037-4051.

Garzanti, E., Andò, S., Padoan, M., Vezzoli, G., Vermeesch, P., Lustrino, M., 2014c. Ultra-long distance littoral transport of Orange sand and provenance of the Skeleton Coast Erg (Namibia). Marine Geology, 357, 25-36.

Garzanti, E., Andó, S., Vezzoli G., 2009. Grain-size dependence of sediment composition and environmental bias in provenance studies. Earth and Planetary Science Letters, 277, 422-432.

Garzanti, E., Dinis, P., Vermeesch, P., Andò, S., Hahn, A., Huvi, J., Limonta, M., Padoan, M, Resentini, A., Rittner, M., Vezzoli, G. Sedimentary processes controlling ultralong cells of littoral transport: Placer formation and termination of the Orange sand highway in southern Angola. Sedimentology, DOI: 10.1111/sed.12387

Garzanti, E., Padoan, M., Setti, M., López-Galindo, A., Villa, I.M., 2014a. Provenance versus weathering control on the composition of tropical river mud (southern Africa). Chemical Geology, 366, 61-74.

Garzanti, E., Padoan, M., Setti, M., Peruta, L., Najman, Y., Villa, I.M., 2013a. Weathering geochemistry and $\mathrm{Sr}-\mathrm{Nd}$ isotope fingerprints of equatorial upper Nile and Congo muds. Geochemistry, Geophysics, Geosystems, 14, 292-316.

Garzanti, E., Resentini, A., 2016. Provenance control on chemical indices of weathering (Taiwan river sands). Sedimentary Geology, 336, 81-95.

Garzanti, E., Vermeesch, P., Padoan, M., Resentini, A., Vezzoli, G., Andó, S., 2014b. Provenance of passive-margin sand (southern Africa). Journal of Geology, 122, 17-42.

Gordon, A.L., Bosley, K.T., 1991. Cyclonic gyre in the tropical South Atlantic. Deep-Sea Res., 38, 323-343.

Haddon, I.G., McCarthy, T.S., 2005. The Mesozoic-Cenozoic interior sag basins of Central Africa: The Late-Cretaceous-Cenozoic Kalahari and Okavango basins. Journal of African Earth Sciences, 43, 316-333. 
Hastenrath, S., 2012. Climate and Circulation of the Tropics (Vol. 8). Springer Science \& Business Media.

Heilborn, M., Valeriano, C.M., Tassinari, C.C.G., Almeida, J., Tupinambá, M., Siga Jr, O., Trouw, R., 2008. Correlation of Neoproterozoic terranes between the Ribeira Belt, SE Brazil and its African counterpart: comparative tectonic evolution and open questions. In: Pankhurst, R. J., Trouw, R. A. J., Brito Neves, B.B., Wit, M.J. (Eds.), West Gondwana: Pre-Cenozoic Correlations Across the South Atlantic Region. Geological Society, London, Spec. Publ. 294, pp. 211-237.

Hijmans, R.J., S.E. Cameron, J.L. Parra, P.G. Jones A. Jarvis, 2005. Very high resolution interpolated climate surfaces for global land areas. International Journal of Climatology, 25, 1965-1978.

Hu, Z., Gao, S., 2008. Upper crustal abundances of trace elements: a revision and update. Chemical Geology, 253, 205-221.

Kahle, M., Kleber, M., Jahn, R., 2002. Review of XRD-based quantitative analyses of clay minerals in soils: the suitability of mineral intensity factors. Geoderma, 109, 191-205.

Kostianoy, A.G., Lutjeharms, J.R.E., 1999. Atmospheric effects in the Angola-Benguela frontal zone. Journal of Geophysical Research: Oceans, 104(C9), 20963-20970.

Lancaster, N., 2002. How dry was dry?-Late Pleistocene palaeoclimates in the Namib Desert. Quaternary Science Reviews, 21, 769-782.

Marzoli, A., Melluso, L., Morra, V., Renne, P.R., Sgrosso, I., D'Antonio, M., Duarte, L., Morais, E.A.A., Ricci, G., 1999. Geochronology and petrology of Cretaceous basaltic magmatism in the Kwanza basin (western Angola), and relationship with the Paranà-Etendeka continental flood basalt province. Journal of Geodynamics, 28, 341-356.

Mclennan, S.M., Hemming, S., Mcdaniel, D.K., Hanson, G.N., 1993, Geochemical approaches to sedimentation, provenance and tectonics. In: Johnsson, M.J., Basu, A. (Eds.), Processes Controlling the Composition of Clastic Sediments: Geological Society of America, Special Paper 284, pp. 21-40.

Meeuwis, J.M., Lutjeharms, J.R.E., 1990. Surface thermal characteristics of the Angola-Benguela front. South African Journal of Marine Science, 9, 261-279.

Miller, R.M., 2008. The geology of Namibia. Geological Survey of Namibia, Windhoek.

Moore, D., Reynolds, R., 1997. X-Ray-Diffraction and the identification and analysis of clay minerals. Oxford University Press, New York.

Morton, A. C., Hallsworth, C., 2007. Stability of detrital heavy minerals during burial diagenesis. Developments in Sedimentology, 58, 215-245.

Moulin, M., Aslanian, D., Unternehr, P., 2010. A new starting point for the South and Equatorial Atlantic Ocean. Earth-Science Reviews, 98, 1-37.

Moulin, M., Aslanian, D., Olivet, J.-L., Contrucci, I., Matias, L., Géli , L., Klingelhoefer, F., Nouzé, H., Réhault, J.-P., Unternehr, P., 2005. Geological constraints on the evolution of the Angolan 
margin based on reflection and refraction seismic data (ZaïAngo project). Geophysical Journal International, 162, 793-810.

Nesbitt, H.W., Markovics, G., Price, R.C., 1980. Chemical processes affecting alkalis and alkali earths during continental weathering. Geochim. Cosmochim. Acta, 44, 1659-1666.

Nesbitt, H.W., Young, G.M., 1982. Early Proterozoic climates and plate motions inferred from major element chemistry of lutites. Nature, 299, 715-717.

Parker, A., 1970. An index of weathering for silicate rocks. Geological Magazine, 107, 501-504.

Peel, M.C., Finlayson, B.L., McMahon, T.A., 2007. Updated world map of the Koppen-Geiger climate classification. Hydro. Earth Syst. Sci., 11, 1633-1644.

Pereira, E., Tassinari, C.C.G., Rodrigues, J.F., Van-Dúnem, M.V., 2011. New data on the deposition age of the volcano-sedimentary Chela Group and its Eburnean basement: implications to post-Eburnean crustal evolution of the SW of Angola. Comunicações Geológicas, 98, 29-40.

Petschick, R., Kuhn, G., Gingele, F., 1996. Clay mineral distribution in surface sediments of the South Atlantic: sources, transport, and relation to oceanography. Marine Geology, 130, 203-230.

Price, R.C., Gray, C.M., Wilson, R.E., Frey, F.A., Taylor, S.R., 1991. The effects of weathering on rare-earth element, $\mathrm{Y}$ and $\mathrm{Ba}$ abundances in Tertiary basalts from southeastern Australia. Chemical Geology, 93, 245-265.

Renne, P.R., Glen, J.M., Milner, S.C., Duncan, A.R., 1996. Age of Etendeka flood volcanism and associated intrusions in southwestern Africa. Geology, 24, 659-662.

Rudnick, R.L., Gao, S., 2003. Composition of the continental crust. In: Rudnick, R.L., Holland, H.D., Turekian, K.K. (Eds.), Treatise on geochemistry, vol. 3, The crust. Elsevier Pergamon, Oxford, pp. 1-64.

Schultz, L.G., 1964. Quantitative interpretation of mineralogical composition from X-Ray and chemical data for the Pierre Shale. U. S. Geological Survey, Professional Paper 391-C.

Séranne, M., Anka, Z., 2005. South Atlantic continental margins of Africa: a comparison of the tectonic vs climate interplay on the evolution of equatorial west Africa and SW Africa margins. Journal of African Earth Sciences, 43, 283-300.

Shannon, L.V., Nelson, G., 1996. The Benguela: large scale features and processes and system variability. In: Wefer, W.H.B.G., Siedler, G., Webb, D. (Eds.), The South Atlantic: present and past circulation. Springer, Berlin, pp. 163-210.

Tack, L., Wingate, M.T.D., Liégeois, J.P., Fernandez-Alonso, M., Deblond, A., 2001. Early Neoproterozoic magmatism (1000-910 Ma) of the Zadinian and Mayumbian Groups (BasCongo): onset of Rodinia rifting at the western edge of the Congo craton. Precambrian Research, 110, 277-306.

Vaughan, A.P., Pankhurst, R.J., 2008. Tectonic overview of the West Gondwana margin. Gondwana Research, 13, 150-162.

Vermeesch, P., Garzanti, E., 2015. Making geological sense of 'Big Data' in sedimentary provenance analysis. Chemical Geology, 409, 20-27. 
629 Vermeesch, P., Resentini, A., Garzanti, E., 2016. An R package for statistical provenance analysis. 630 Sedimentary Geology, 336, pp.14-25.

631 von Eynatten, H., Tolosana-Delgado, R., Karius, V., 2012. Sediment generation in modern glacial 632 settings: source-rock and grain-size control on sediment composition. Sedimentary Geology, $633280,80-92$.

634 von Eynatten, H., Tolosana-Delgado, R., Karius, V., Bachmann, K., Caracciolo, L., 2016. Sediment 635 generation in humid Mediterranean setting: Grain-size and source-rock control on sediment 636 geochemistry and mineralogy (Sila Massif, Calabria). Sedimentary Geology, 336, 68-80.

637 Wacongne, S., Piton, B. 1992. The near-surface circulation in the northeastern corner of the South 638 Atlantic Ocean. Deep-Sea Res., 39, 1273-1298.

639 
640 Fig. 1: Geology and geomorphology of tropical SW Africa. (A) Location of the study area in the 641 SW Africa. (B) Rainfall (from Hijmans et al., 2005) and (C) soils types (from Food and Agriculture 642 Organization, www.britannica.com/bps/media-view/19257/0/0/0) on tropical W Africa. (D) 643 Topography and the catchments of the sampled rivers (E) schematic geological map (mainly from 644 Araújo and Perevalov, 1998) of the studied region. Tectonic domains and stratigraphic assignments 645 based on Carvalho et al. (2000), Heilborn et al. (2008) and Ernst et al. (2013). CB: Congo Basin; 646 KB: Cuanza Basin; BB: Benguela Basin; KSM: Cuanza Seamount. Location of the studied samples 647 is also shown; small white circles indicate complementary samples not considered for this research. 648 649 650 651 652 653 654 655 656 657 658 659 660 661 662 663 664 665 666 667 668 669 670 671 672 673

Fig. 2: Spatial (latitudinal) variation of clay minerals abundances in river muds. Only sediments from the Atlantic margin are considered.

Fig. 3: Spatial (latitudinal) variation of selected geochemical weathering indices in fluvial and coastal sediments. Only fluvial samples collected in the Atlantic margin are represented.

Fig. 4: Principal Component Analysis (PCA) of the sediment compositions along the Angolan coast. Up: River, beach and aeolian sand samples. Down: mud samples. Left: the PCA scores (eigenvalues) of the samples, labeled with the sample latitudes for brevity. River samples are coloured blue (north), red (south) or green (intermediate latitudes). Beach and dune samples are coloured grey. Right: the loadings (eigenvectors) of the principal components. Long arrows mark elements which are most effective in explaining the spread of the data. Arrows pointing in the same direction mark covariant elements, while variables attached to arrows intersecting at right angles are mutually independent (Aitchison and Greenacre, 2002).

Fig. 5: 3-way Multidimensional Scaling (MDS) analysis of the combined sand and mud compositions generated using Vermeesch et al. (2016)'s provenance package (version 1.5). Left: the 'group configuration' represents a consensus view of the five different levels of comparison between the samples. Colours are identical to Figure 4, but labels mark the names of the rivers rather than their latitudes. Right: the 'source weights' of the five different levels of comparison, revealing that the horizontal and vertical dimensions of the group configuration are dominated by 
674 the sand and clay compositions, respectively. This leads to the geological interpretation that vertical 675 distances in the group configuration correspond to differences in weathering intensity, while 676 horizontal distances are caused by differences in provenance.

677

678

679

680

681

682

683

684

685

686

687

688

689

690

691

692

693

694

695

696

697

698

699

700

701

702

Fig. 6: Relation between the aerial proportion of the Meso-Cenozoic Atlantic basins in the catchment areas of the studied river samples and expansive clays abundance, $\alpha^{\mathrm{Al}} \mathrm{Mg}$ in river muds and $\alpha^{\mathrm{Al}} \mathrm{Ca}$ in river sands.

Fig. 7: Binary scatters of CIX vs. WIP weathering indices. Cn: Kunene; Ln: Longa; Bg: Bengo; Cz: Cuanza; encircled samples were collected in coastal stretches with basement outcrops.

Fig. 8: Plots of $\mathrm{Th} / \mathrm{Sc}$ vs. $\mathrm{Zr} / \mathrm{Sc}$ with weathering parameters represented as bubbles (bubble diameter proportional to the value of the weathering proxy). Values of $\mathrm{CIX}, \alpha^{\mathrm{Al}} \mathrm{Na}$ and $\alpha^{\mathrm{Al}} \mathrm{Mg}$ were previously normalized by scaling between 0.01 and 1 .

Fig. 9: Correlation coefficients of weathering parameters for fluvial sediments and the average annual rainfall in the corresponding catchment areas. Plots for the best correlations are shown below. Best correlations were determined for $\alpha^{\mathrm{Al}} \mathrm{Na}$ in sands, $\alpha^{\mathrm{Al}} \mathrm{Mg}$ in muds and smectite content. Correlation smectite-rainfall is only valid for catchments with low rainfall (i.e., relatively small catchments and preferentially at higher latitudes). Relations with rainfall improve by excluding small and anomalously felsic catchments, for $\alpha^{\mathrm{Al}} \mathrm{Mg}$, and low rainfall catchments, for $\alpha^{\mathrm{Al}} \mathrm{Na}$. GIS tools applied to the Hijmans et al. (2005) climate data (30 sec. spatial resolution) were used to calculate annual rainfall in each catchment area. Hinterland samples, which frequently comprise an extensive sedimentary cover in the catchment areas, are not represented. 

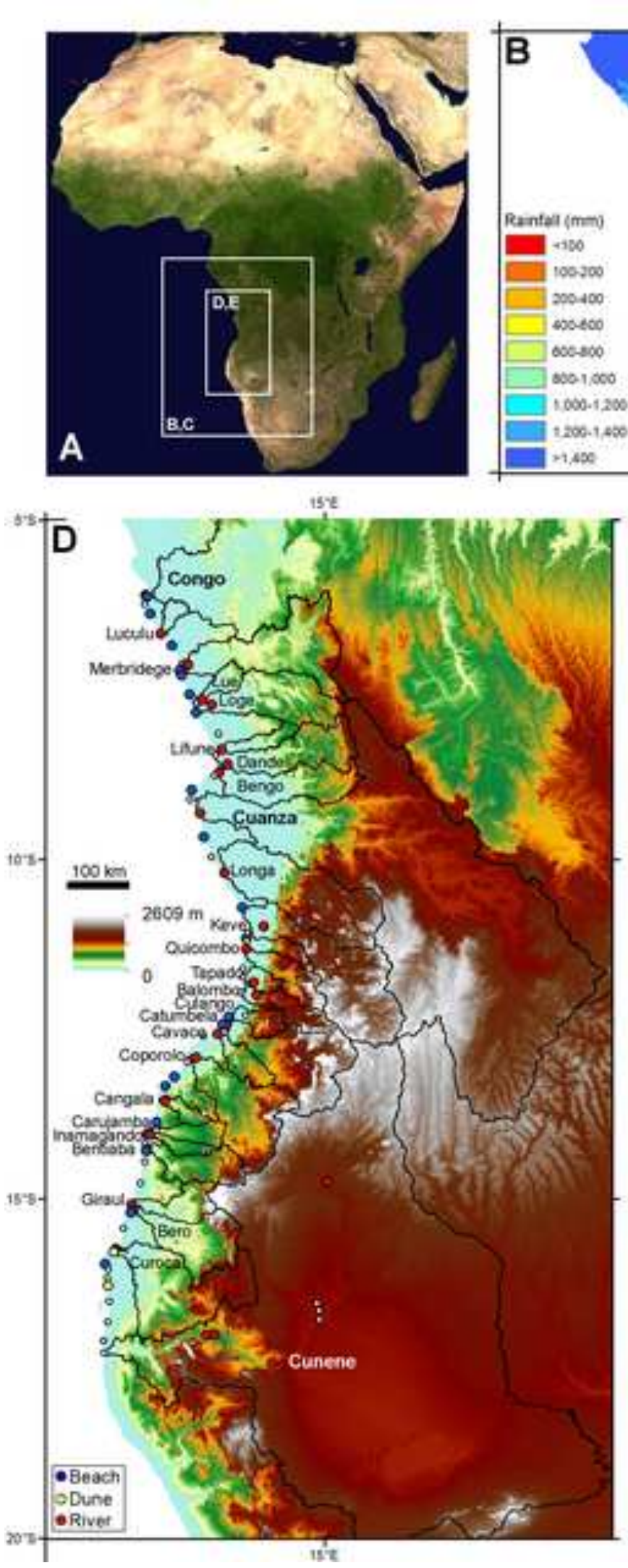
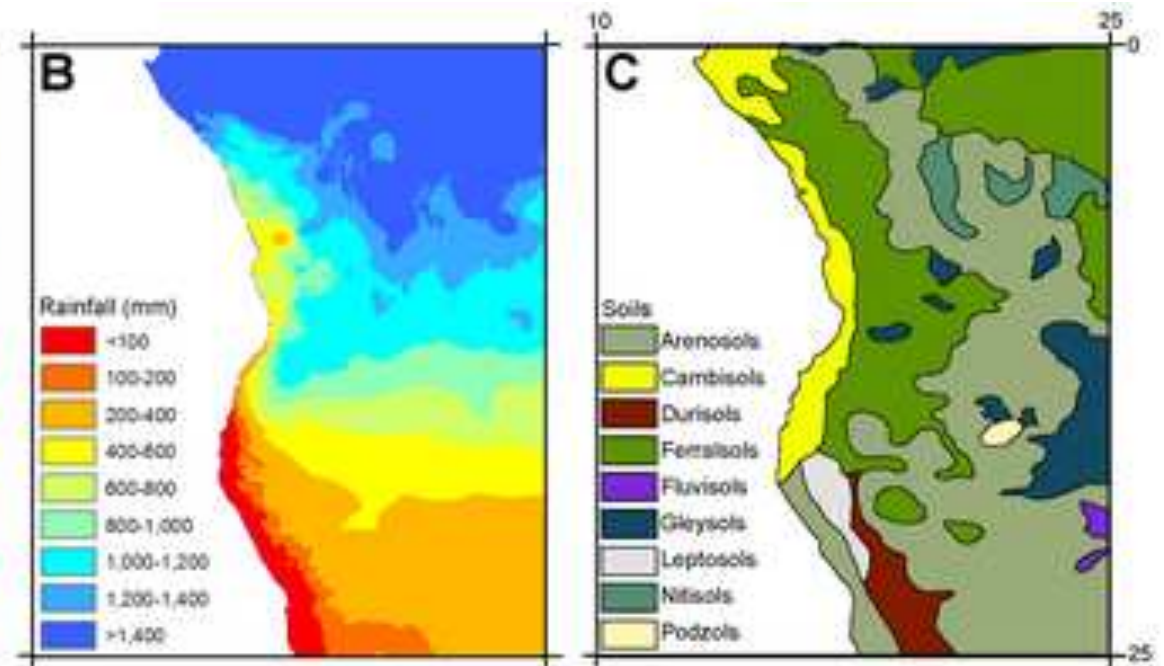

$20 \mathrm{E}$

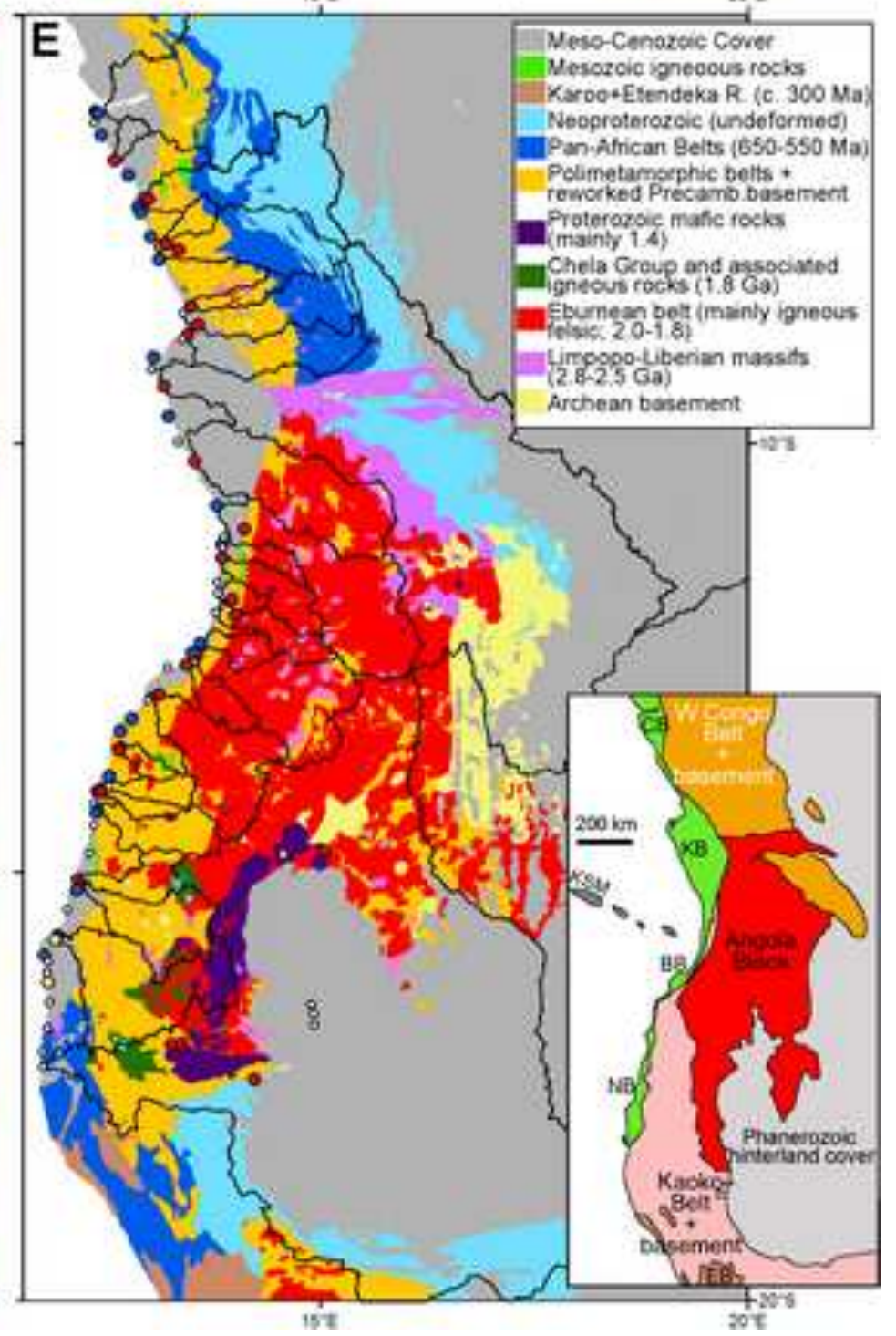




\section{Cumulative abundances}

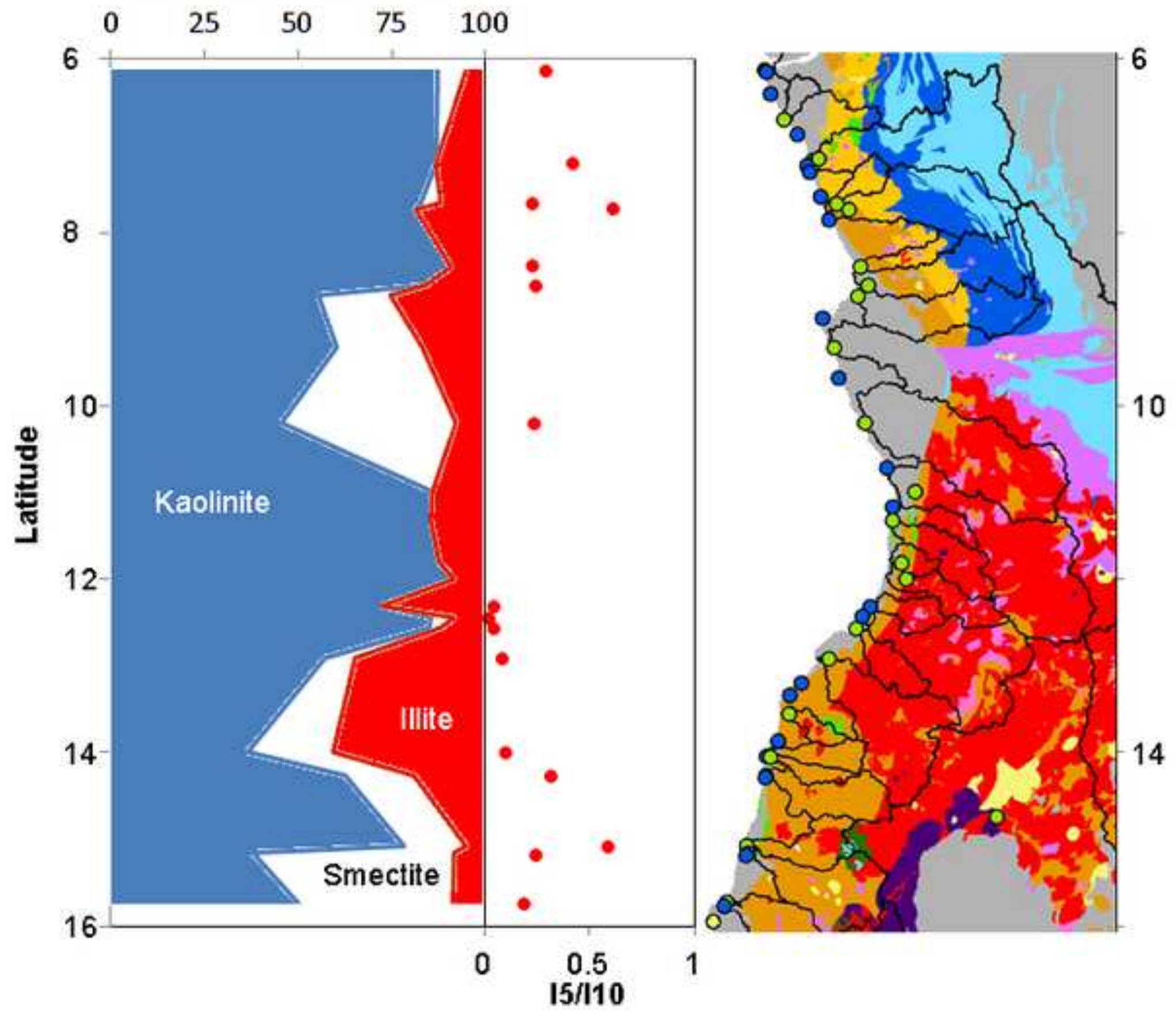




\section{River muds}

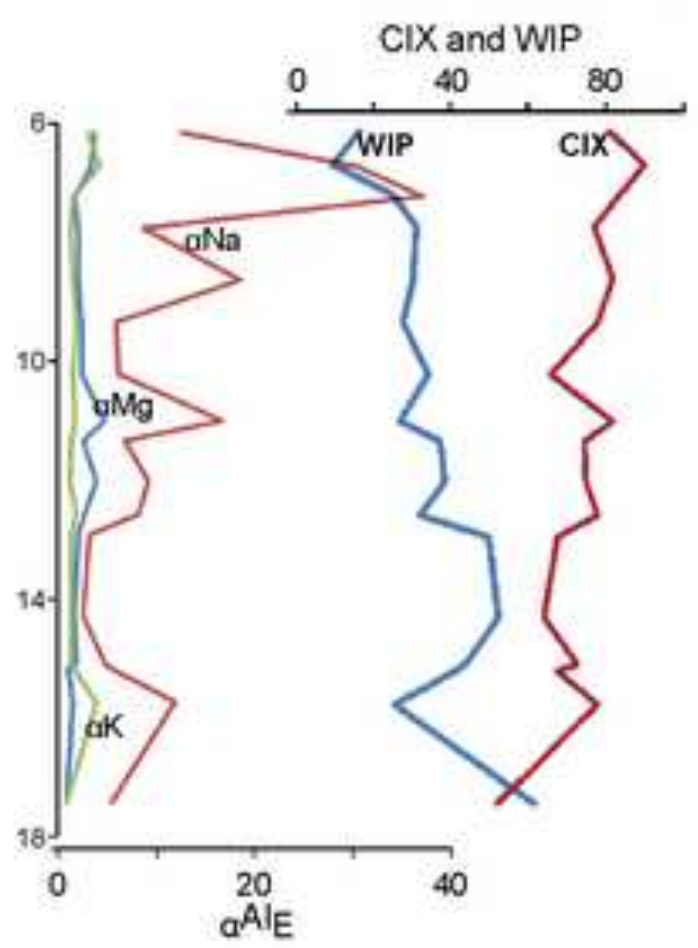

\section{River sands}

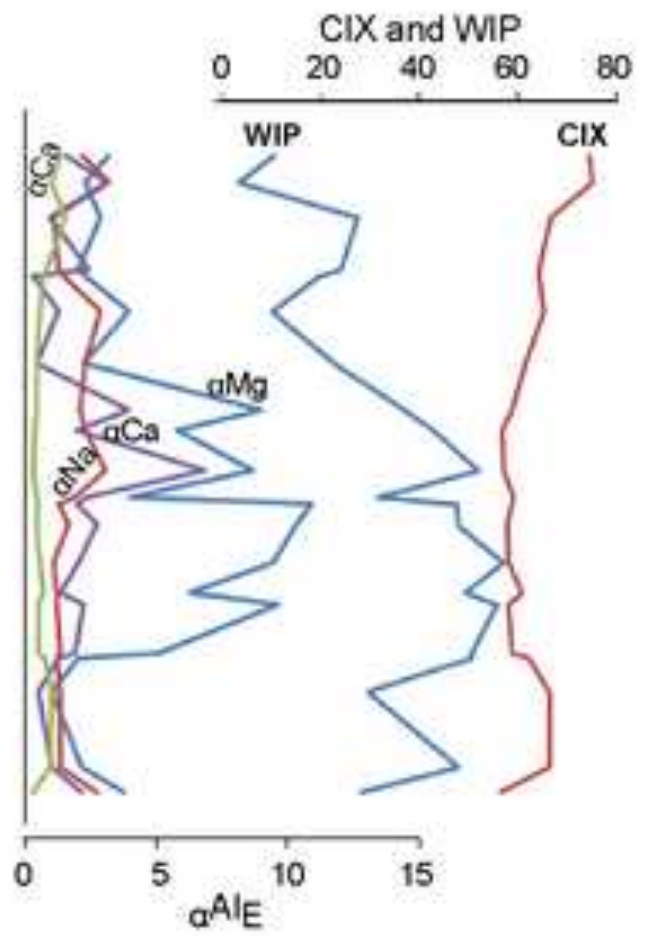

\section{Beach/aeolian sands}

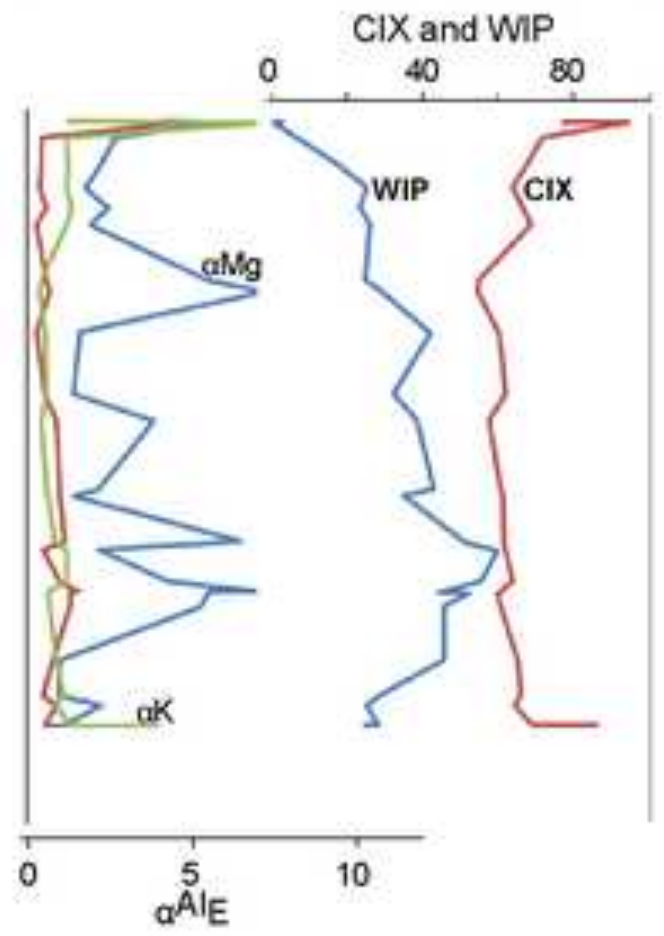

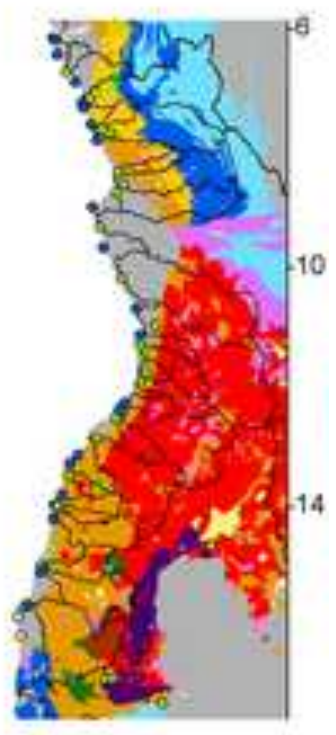


Click here to download high resolution image
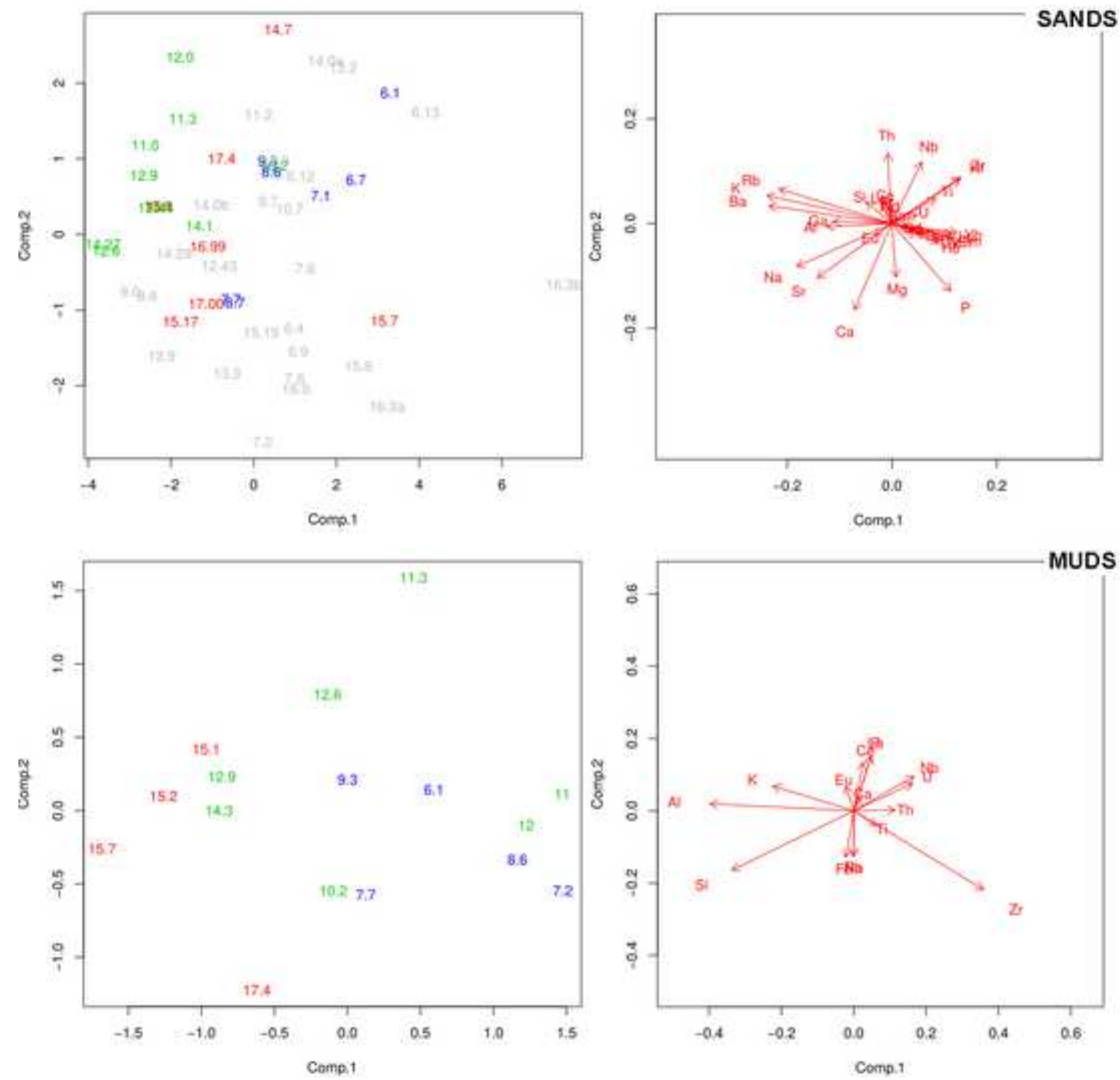

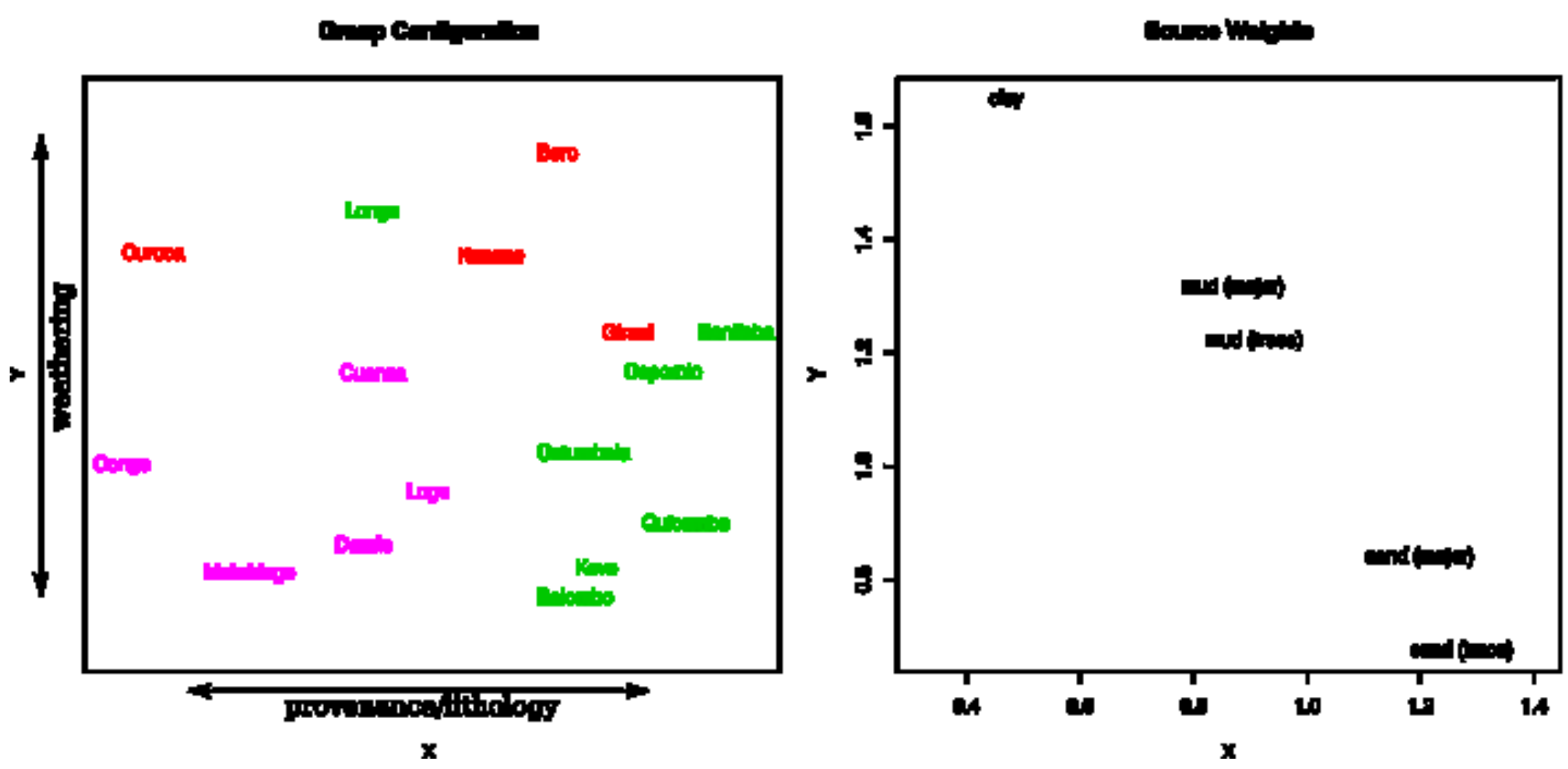
Click here to download high resolution image
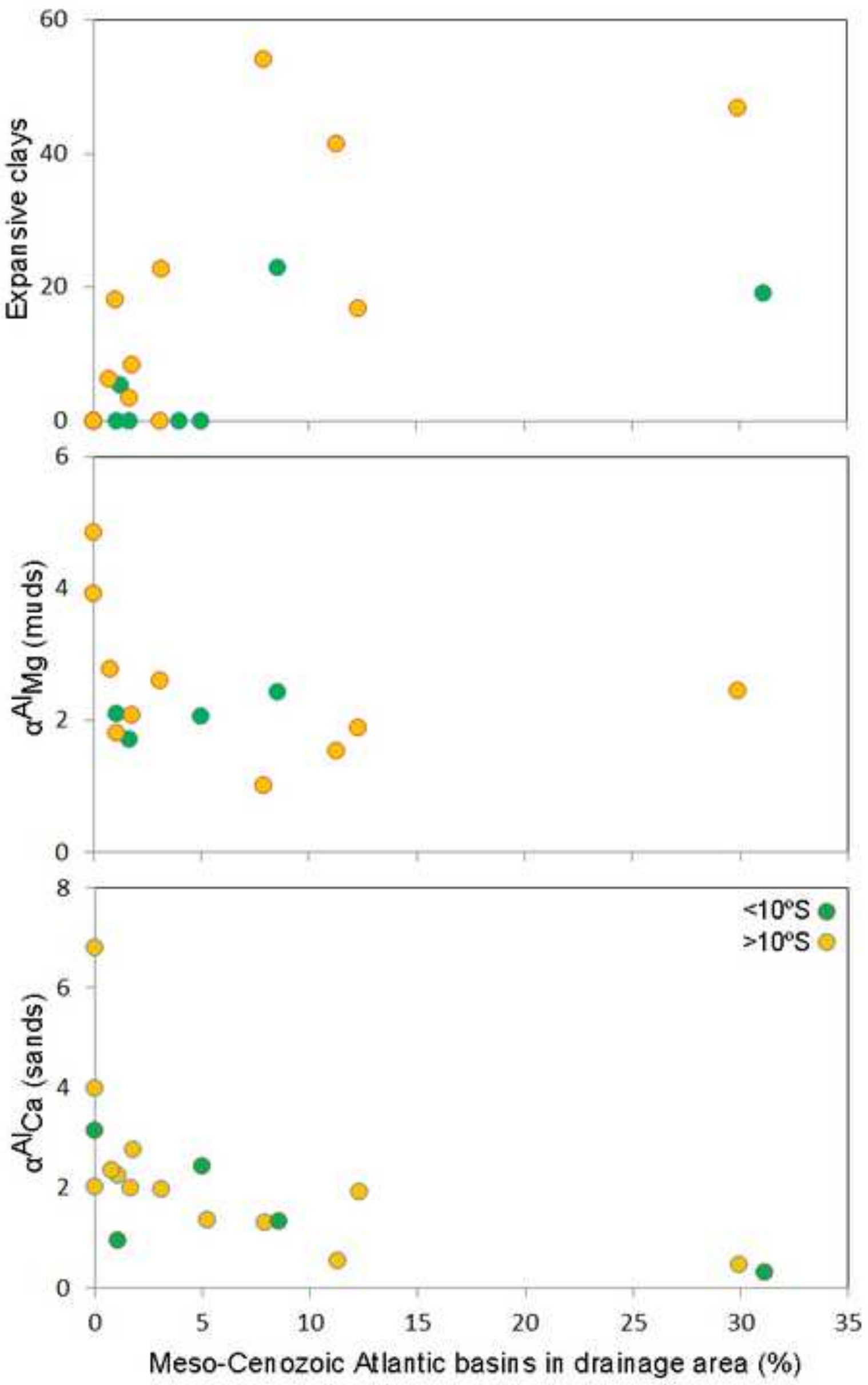
Click here to download high resolution image
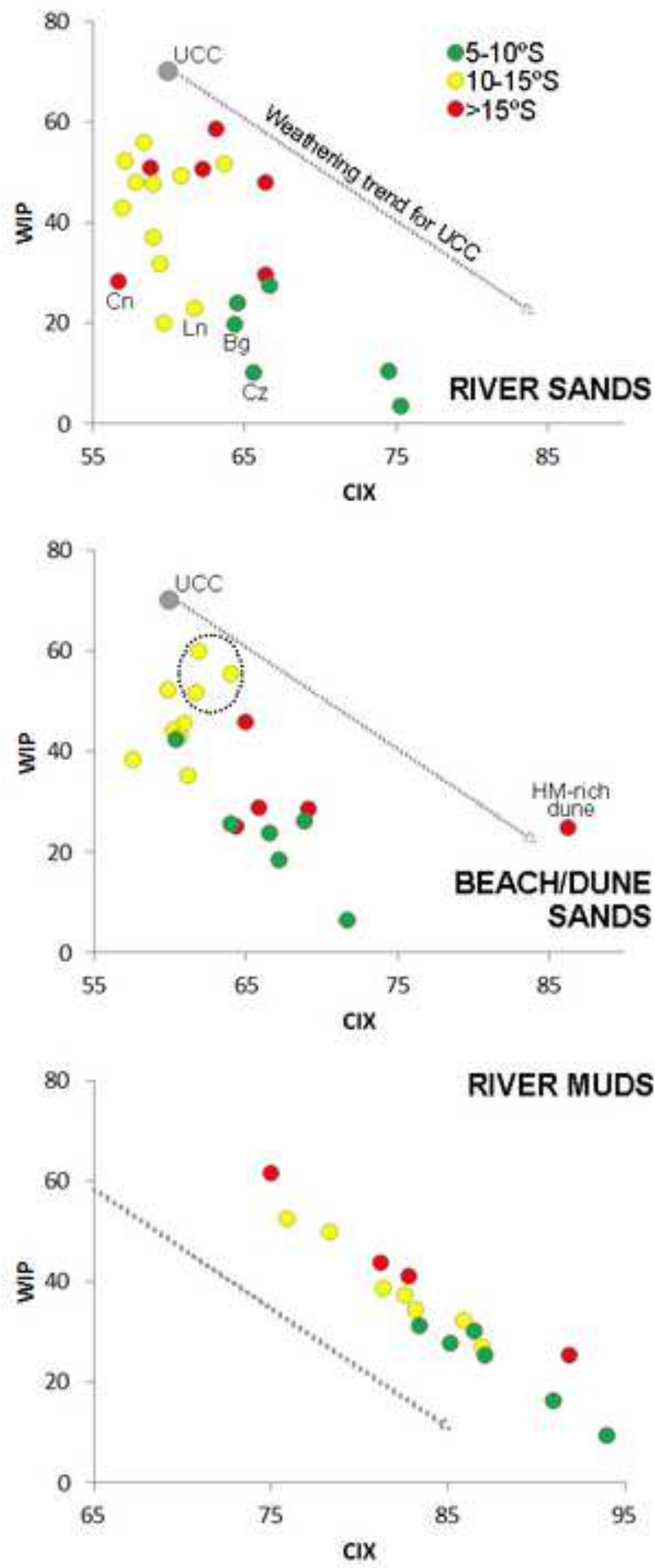

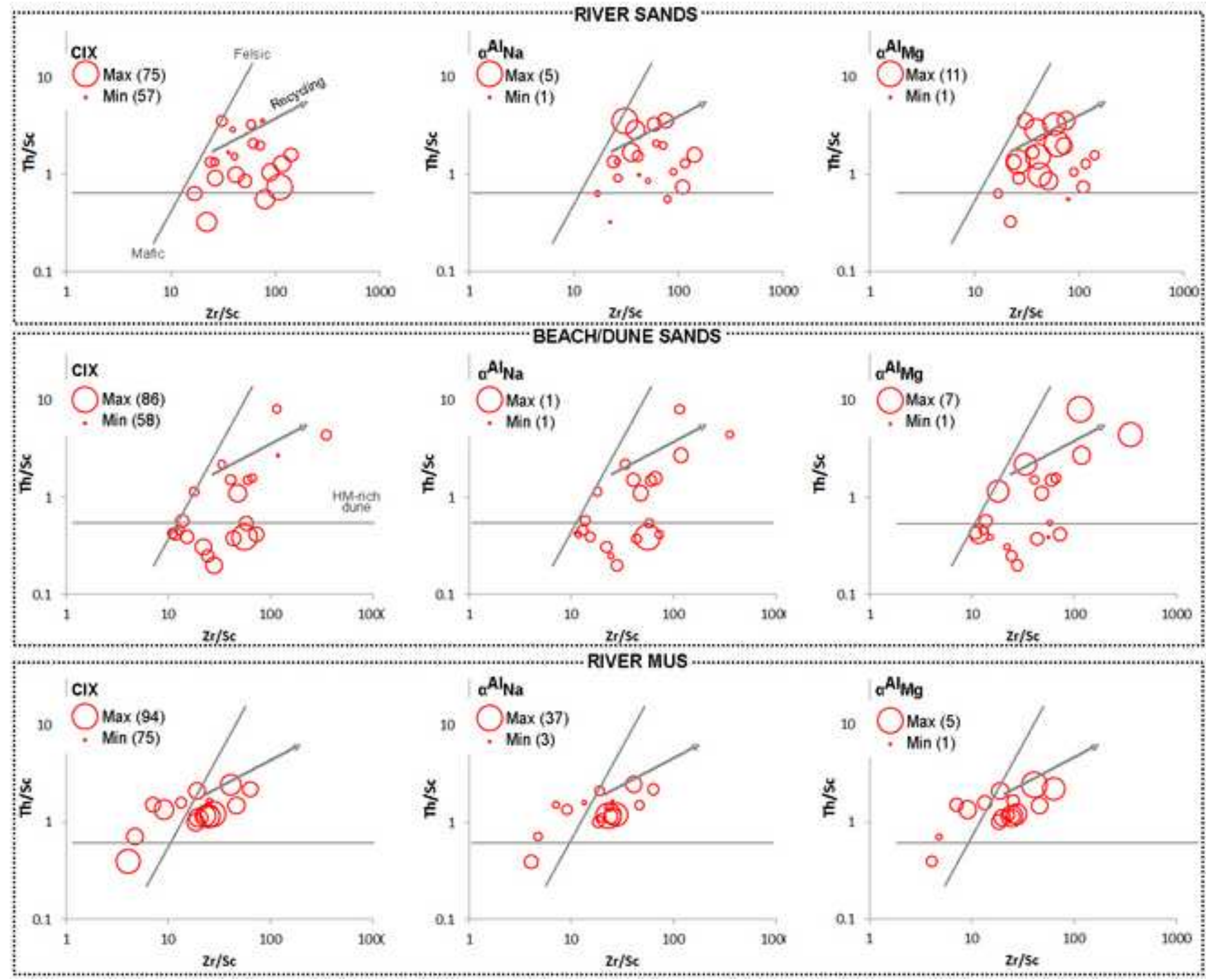

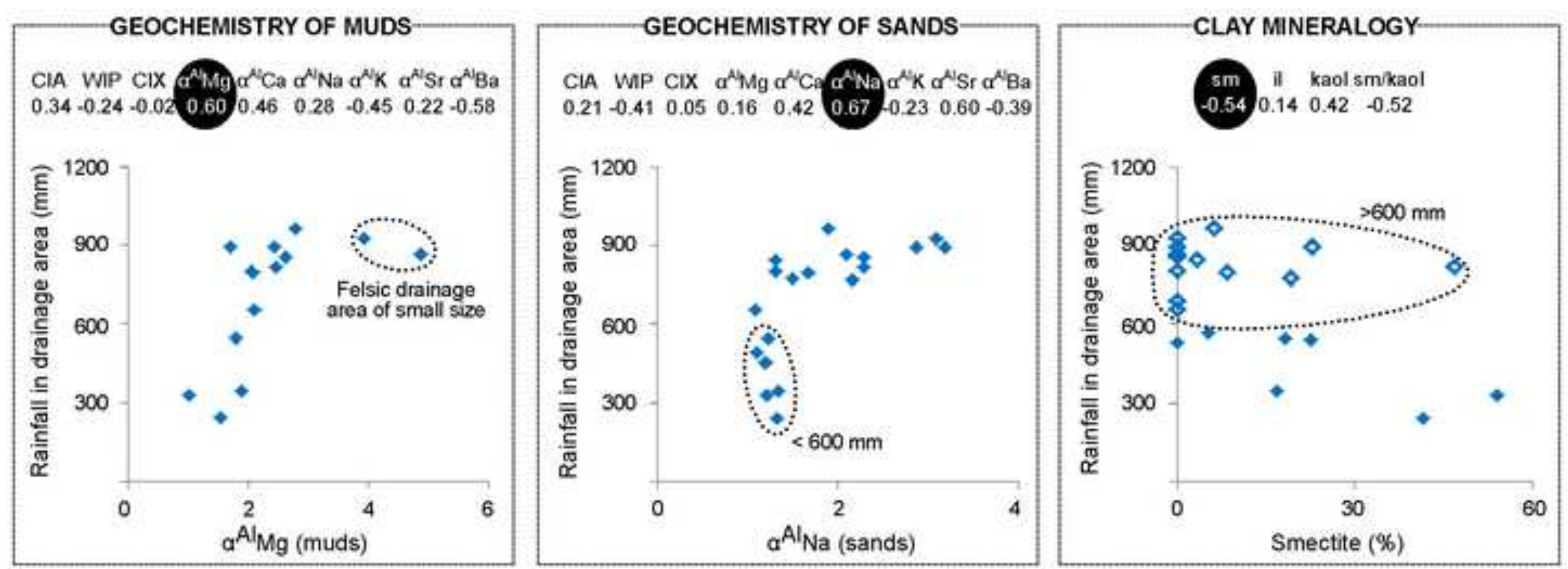
Table 1: Weathering indices considered in this work

\begin{tabular}{|l|l|l|}
\hline Index & Formula & Reference \\
\hline $\mathrm{CIA}$ & $\mathrm{Al}_{2} \mathrm{O}_{3} /\left(\mathrm{Al}_{2} \mathrm{O}_{3}+\mathrm{K}_{2} \mathrm{O}+\mathrm{CaO}+\mathrm{Na}_{2} \mathrm{O}\right) * 100$ & Nesbitt and Young (1982) \\
\hline $\mathrm{CIX}$ & $\mathrm{Al}_{2} \mathrm{O}_{3} /\left(\mathrm{Al}_{2} \mathrm{O}_{3}+\mathrm{K}_{2} \mathrm{O}+\mathrm{Na}_{2} \mathrm{O}\right) * 100$ & Garzanti et al. (2014a) \\
\hline WIP & $\left(\mathrm{CaO} / 0.7+2 \mathrm{Na}_{2} \mathrm{O} / 0.35+2 \mathrm{~K}_{2} \mathrm{O} / 0.25+\mathrm{MgO} / 0.9\right) * 100$ & Parker (1970) \\
\hline$\alpha^{\mathrm{Al}}{ }_{\mathrm{E}}$ & $\begin{array}{l}(\mathrm{Al} / \mathrm{E})_{\text {sample }} /(\mathrm{Al} / \mathrm{E})_{\text {Ucc, }} \text {, being E a mobile element } \\
(\mathrm{Na}, \mathrm{Ca}, \mathrm{Sr}, \mathrm{Mg}, \mathrm{K}, \mathrm{Ba} \text { or Rb) }\end{array}$ & Garzanti et al. (2013a) \\
\hline
\end{tabular}


